\title{
SOL-GEL INCORPORATION OF ORGANOMETALLIC COMPOUNDS INTO SILICA: USEFUL PRECURSORS TO METALLIC NANOSTRUCTURED MATERIALS
}

\author{
CARLOS DIAZ ${ }^{a}$, MARIA LUISA VALENZUELA ${ }^{b}$, DENISSE GARRIDO ${ }^{a}$ AND PEDRO AGUIRRE
}

\author{
${ }^{a}$ Departamento de Química, Facultad de Ciencias, Universidad de Chile, Las Palmeras 3425, Nuñoa Casilla 653, Santiago, Chile. \\ ${ }^{b}$ Universidad Andres Bello, Departamento de Ciencias Quimica, Facultad de Ciencias Exactas, Av. Republica 275, Santiago, Chile. \\ c Departamento de Química Analítica e Inorgánica, Facultad de Ciencias Químicas y Farmacéuticas, Universidad de Chile, casilla 233, Santiago, Chile. \\ (Received: October 12, 2011 - Accepted: March 22, 2012)
}

\begin{abstract}
Inclusion of the organometallic MLn $=\left[\mathrm{HOC}_{5} \mathrm{H}_{4} \mathrm{~N} \cdot \mathrm{Cp}_{2} \mathrm{TiCl}\right]\left[\mathrm{PF}_{6}\right](\mathbf{1}), \mathrm{HOC}_{5} \mathrm{H}_{4} \mathrm{~N} \cdot \mathrm{W}(\mathrm{CO})_{5}(\mathbf{2}), \mathrm{HOC}_{5} \mathrm{H}_{4} \mathrm{~N} \mathrm{Mo}(\mathrm{CO})_{5}(\mathbf{3}),\left[\mathrm{HOC}_{6} \mathrm{H}_{4} \mathrm{CH}_{2} \mathrm{CN} \cdot \mathrm{Cp}_{2} \mathrm{TiCl}\right][\mathrm{PF} 6]$ (4), $\mathrm{HOC}_{6} \mathrm{H}_{4} \mathrm{CH}_{2} \mathrm{CN} \cdot \mathrm{W}(\mathrm{CO})_{5}(\mathbf{5})$ and $\mathrm{HOC}_{6} \mathrm{H}_{4} \mathrm{CH}_{2} \mathrm{CN} \bullet \mathrm{Mo}(\mathrm{CO})_{5}(\mathbf{6})$ into amorphous silica using the gelator precursor TEOS and $\mathrm{N}_{3} \mathrm{P}_{3}\left\{\mathrm{NH}[\mathrm{CH}]_{3} \mathrm{Si}_{3}[\mathrm{OEt}]_{3}\right\}_{6}$ afford the gels $(\mathrm{MLn})\left(\mathrm{SiO}_{2}\right)_{\mathrm{n}}$. The inorganic-organic hybrid nanocomposites were pyrolyzed under air at $800^{\circ} \mathrm{C}$ to give nanostructured metal oxides and/or metal pyrophosphates (phosphates) included in the silica matrices. The morphology of the monolithic nanocomposites exhibited a strong dependence on the gel precursor used being mainly laminar for those prepared using $\mathrm{N}_{3} \mathrm{P}_{3}\left\{\mathrm{NH}\left[\mathrm{CH}_{2}\right]_{3} \mathrm{Si}[\mathrm{OEt}]_{3}\right\}$ as gelator. TEM images show different shape and size such as circular nanoparticles, nanocables and agglomerates in some cases with sizes of $20 \mathrm{~nm}$ for the circular nanostructures, and diameter about $25 \mathrm{~nm}$ for the nanocables.
\end{abstract}

Keywords Sol-gel, Nanostructured, Nanocomposites, Pyrophosphates.

\section{INTRODUCTION}

Since the Ebelmen discovery of the polymerization of TEOS(tetraethoxysilane) $)^{1}$ to give amorphous $\mathrm{SiO}_{2}$, great amounts of the material glasses and other have appeared ${ }^{2,3}$. When an organic moiety was attached to the $\mathrm{Si}(\mathrm{OR})_{3}$ moiety as $\mathrm{R}-\mathrm{Si}(\mathrm{OR})_{3}$ or $(\mathrm{OR})_{3} \mathrm{Si}-\mathrm{R}-\mathrm{Si}(\mathrm{OR})_{3}$ interesting "hybrid organic-inorganic" materials emerged ${ }^{4,5}$. It was found that the organic groups are capable of modifying the properties of the bulk materials. Also inclusion of some inorganic substrates gives rise to metallic structures included inside the $\mathrm{SiO}_{2}$ matrix ${ }^{6,7}$. Owing to the discovery of the ordered mesoporous $\mathrm{SiO}_{2}$ assisted by surfactants, a new field emerged ${ }^{8,9}$. Actually several organic and inorganic substrates have been included in ordered mesoporous giving rise to interesting materials ${ }^{10,11}$. Organometallic compounds included in periodic mesoporous silica have been also discussed ${ }^{12}$. Although ordered mesoporous silica with substrate included, are the most studied, amorphous form and its inclusion compounds could have also interesting an unforeseen reactivity pattern $^{12}$. Some examples of metal and metal oxides included in amorphous silica have been reported ${ }^{13-24}$

The most used method within this type of materials is the hydrolysis of TEOS in presence of metal salts (usually metal nitrate). By this method for instance metal oxide $/ \mathrm{SiO}_{2}$ as $\mathrm{Fe}_{2} \mathrm{O}_{3} / \mathrm{SiO}_{2}{ }^{13,14}, \mathrm{Cr}_{2} \mathrm{O}_{3} / \mathrm{SiO}_{2}{ }^{15}$ and metal $/ \mathrm{SiO}_{2}$ as $\mathrm{Au} / \mathrm{SiO}_{2}, \mathrm{Ag} / \mathrm{SiO}_{2}, \mathrm{Cu} / \mathrm{SiO}_{2}, \mathrm{Pt} / \mathrm{SiO}_{2}$ and $\mathrm{Pd} / \mathrm{SiO}^{2}, 17$ have been prepared. Another related approximation uses TEOS with metal salts in presence of citric acid for the reduction. $\mathrm{Ni}, \mathrm{Co}, \mathrm{Ag}, \mathrm{Fe} / \mathrm{SiO}_{2}$ composites were obtained ${ }^{18}$. Hydrolysis of the metal/alkoxy as $\mathrm{Cr}\left(\mathrm{O}^{t} \mathrm{Bu}\right)_{4}$ in presence of $\mathrm{HOSi}\left(\mathrm{O}^{t} \mathrm{Bu}\right)_{3}$ affords nanostructured chromium oxides inside amorphous silica ${ }^{19}$. Impregnation of $\mathrm{Cu}\left(\mathrm{NO}_{3}\right)_{2}$ salts in a $\mathrm{SiO}_{2}$ xerogel gives $\mathrm{Cu}_{\mathrm{O}^{2}}{ }^{20}$. Another different approximation to metal oxide/ $\mathrm{SiO}_{2}$ is the use of precursor of the type $\mathrm{MX}_{n} \cdot \mathrm{H}_{2} \mathrm{~N}\left(\mathrm{CH}_{2}\right)_{3} \mathrm{Si}(\mathrm{OEt})_{3}$ with a co-condensation with TEOS to give $\mathrm{MO} \cdot \mathrm{nSiO}_{2}$ nanocomposites ${ }^{21}$. Xia 22 in another way use a novel procedure to obtain nanocables of $\mathrm{Ag}$ covered with amorphous silica. The preformed $\mathrm{Ag}$ nanocables were covered with $\mathrm{SiO}_{2}$ generated using the Stöber procedure.

Only two ways to include organometallic compounds inside amorphous silica have been reported ${ }^{23,24}$. One used the precursor ${ }^{23} \mathrm{MLn} \cdot \mathrm{R}_{2} \mathrm{P}\left(\mathrm{CH}_{2}\right)_{2} \mathrm{Si}(\mathrm{OEt})_{3}$, MLn $=\mathrm{Fe}(\mathrm{CO})_{5}, \quad \mathrm{RuCl}_{2}\left(\eta^{6}\right.$-cymene $), \mathrm{Co}_{2}(\mathrm{CO})_{9}$, and hydrolyzing in presence of $\mathrm{Si}\left(\mathrm{OCH}_{3}\right)_{4}^{23}$. The another approximation uses the precursor cis$\mathrm{Ru}\left(\mathrm{Cl}\left((\mathrm{CO})_{2} \mathrm{P}(\mathrm{R})\left(\mathrm{R}^{3}\right)\left(\mathrm{CH}_{2}\right)_{\mathrm{x}} \mathrm{Si}\left(\mathrm{OCH}_{3}\right)_{3}\right.\right.$ in presence of $\mathrm{TEOS}^{24}$. Here we report a new simple way to include the organometallics $\left[\mathrm{HOC}_{5} \mathrm{H}_{4} \mathrm{~N} \cdot \mathrm{Cp}_{2} \mathrm{TiCl}\right][\mathrm{PF}$, $\mathrm{HOC}_{5} \mathrm{H}_{4} \mathrm{~N} \cdot \mathrm{W}(\mathrm{CO})_{5}, \quad \mathrm{HOC}_{5} \mathrm{H}_{4} \mathrm{~N} \cdot \mathrm{Mo}(\mathrm{CO})_{5}, \quad\left[\mathrm{HOC}_{6} \mathrm{H}_{4} \mathrm{CH}_{2} \mathrm{CN} \cdot \mathrm{Cp}_{2} \mathrm{TiCl}\right]\left[\mathrm{PF}_{6}\right]$, $\mathrm{HOC}_{6} \mathrm{H}_{4} \mathrm{CH}_{2} \mathrm{CN} \bullet \mathrm{W}(\mathrm{CO})_{5}$ and $\mathrm{HOC}_{6} \mathrm{H}_{4} \mathrm{CH}_{2} \mathrm{CN} \cdot \mathrm{Mo}(\mathrm{CO})_{5}$ inside amorphous silica. The inclusion was performed by Sol-gel method using TEOS and $\mathrm{N}_{3} \mathrm{P}_{3}\left\{\mathrm{NH}\left[\mathrm{CH}_{2}\right]_{3} \mathrm{Si}[\mathrm{OEt}]_{3}\right\}_{6}$ as agent gelant and in presence of the respective organometallic dissolved in the adequate solvent. $\mathrm{N}_{3} \mathrm{P}_{3}\left\{\mathrm{NH}\left[\mathrm{CH}_{2}\right]_{3} \mathrm{Si}[\mathrm{OEt}]_{3}\right\}_{6}$ was, for the first time used as gelator.

Pyrolysis of these gels at $800{ }^{\circ} \mathrm{C}$ under air affords nanostructured metal oxides and metal phosphates inside the silica. To the best our knowledgement the organometallic complexes (1-6) included in amorphous silica have been not reported. The organometallic (1-6) were select with the aim to obtain nanostructured with $\mathrm{Ti}, \mathrm{W}$ and Mo containing nanostructured materials inside $\mathrm{SiO}_{2}$. Here we report a simple, suitable and general way to prepare metallic nanostructured nanoparticles as metal oxides and phosphates, inside amorphous silica from organometallic precursors see figure 1 . We have previously shown the preparation of nanostructured materials from pyrolysis of molecular and macromolecular precursors ${ }^{25-29}$.
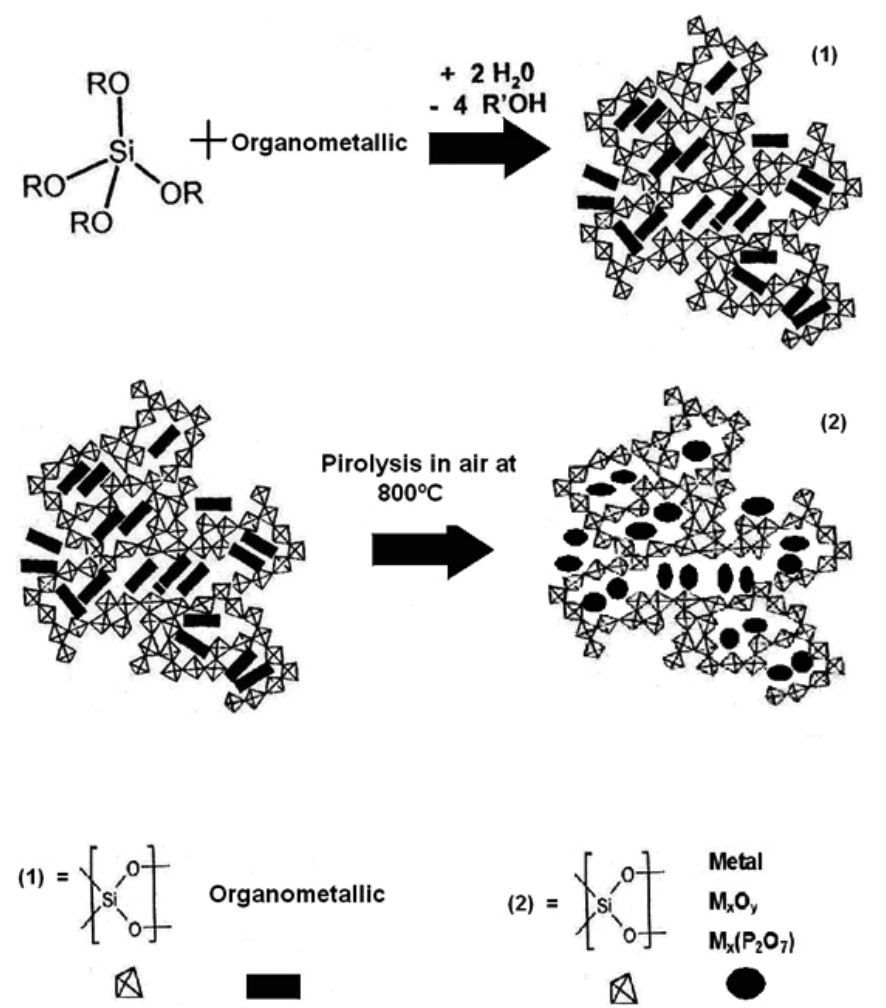

Fig. 1 Schematic representation of the Sol-gel/pyrolysis method to obtain nanostructured metallic, materials inside amorphous silica.

\section{EXPERIMENTAL}

Organometallic precursor preparation

All reactions were run under dry argon using standard Schlenk techniques unless otherwise noted. 4- $\left.\mathrm{HOC}_{5} \mathrm{H}_{4} \mathrm{~N}, 4-\mathrm{HOC}_{6} \mathrm{H}_{4} \mathrm{CH}_{2} \mathrm{CN}, \mathrm{MoCO}\right)_{6}, \mathrm{~W}(\mathrm{CO})_{6}$, 
$\mathrm{Si}(\mathrm{OEt})_{4}$ and $\mathrm{NH}_{4} \mathrm{~F}$ were purchased from Aldrich. The complexes (1), (2) and (4) were prepared as previously reported ${ }^{25,28}$.

Preparation of (3) $\mathrm{HOC}_{5} \mathrm{H}_{4} \mathrm{~N} \cdot \mathrm{Mo}(\mathrm{CO})_{5}: 0.51 \mathrm{~g}, 1.93 \mathrm{mmol}$, of MoCO) in methanol $(130 \mathrm{ml})$ was irradiated under a UV- lamp for $45 \mathrm{~min}$. After this the solution was transferred and $0.18 \mathrm{~g}, 1.8 \mathrm{mmol}$, of $\mathrm{HOC}_{5} \mathrm{H}_{4} \mathrm{~N}$ was added under inert atmosphere and stirred for $2 \mathrm{~h}$. Then, the solvent was eliminated under vaccum and the solid washed with diethylether and dried under reduced pressure. IR (KBr) $3225 \mathrm{~cm}^{-1}(\mathrm{vOH}), 1974 \mathrm{~cm}^{-1}(\mathrm{vCO}), 1635 \mathrm{~cm}^{-1}, 1508 \mathrm{~cm}^{-1}$, $1152 \mathrm{~cm}^{-1}, 1189 \mathrm{~cm}^{-1}, 835 \mathrm{~cm}^{-1}$. Elemental analysis: Calc. C $39.09 ; \mathrm{H} 1.62 ; \mathrm{N}$ 4.62. Found C 38.53; H 2.03; N 4.69.

Preparation of (5) $\mathrm{HOC}_{6} \mathrm{H}_{4} \mathrm{CH}_{2} \mathrm{CN} \cdot \mathrm{W}(\mathrm{CO})_{5}: 0.65 \mathrm{~g}, 1.84 \mathrm{mmol}$ of W(CO) 6 in methanol was irradiated under a UV- lamp for $45 \mathrm{~min}$. After this the solution was transferred and $0.26 \mathrm{~g}, 1.95 \mathrm{mmol}$, of $\mathrm{HOC}_{6} \mathrm{H}_{4} \mathrm{CH}_{2} \mathrm{CN}$ was added under inert atmosphere and stirred for $2 \mathrm{~h}$. The solvent was then eliminated under vaccum and the solid washed with diethylether and dried under reduced pressure. IR (KBr) $3422 \mathrm{~cm}^{-1}$ (vOH), $2345 \mathrm{~cm}^{-1}(\mathrm{vCN}), 1936 \mathrm{~cm}^{-1}$ (vCO), $1635 \mathrm{~cm}^{-1}, 1511 \mathrm{~cm}^{-1}, 1241 \mathrm{~cm}^{-1}, 1061 \mathrm{~cm}^{-1}, 1002 \mathrm{~cm}^{-1}, 942 \mathrm{~cm}^{-1}, 578 \mathrm{~cm}^{-1}$. Elemental analysis: Calc. C 36.04; H 1.61; N 3.23. Found C 35.53; H 1.75; N 3.45 .
Preparation of (6) $\mathrm{HOC}_{6} \mathrm{H}_{4} \mathrm{CH}_{2} \mathrm{CN} \cdot \mathrm{Mo}(\mathrm{CO})_{5}: 0.51 \mathrm{~g}, 1.93 \mathrm{mmol}$, of $\mathrm{MoCO})_{6}$ in methanol $(130 \mathrm{ml})$ was irradiated under a UV-lamp for $45 \mathrm{~min}$. After this, the solution was transferred and $0.25 \mathrm{~g}, 1.87 \mathrm{mmol}$, of $\mathrm{HOC}_{6} \mathrm{H}_{4} \mathrm{CH}_{2} \mathrm{CN}$ was added under inert atmosphere and stirred for $2 \mathrm{~h}$. Then, the solvent was eliminated under vaccum and the solid washed with diethylether and dried under reduced pressure. IR $(\mathrm{KBr}) 3367 \mathrm{~cm}^{-1}(\mathrm{vOH}), 2267 \mathrm{~cm}^{-1}$ (vCN), 1987 $\mathrm{cm}^{-1}, 1940 \mathrm{~cm}^{-1}$ (vCO), $1631 \mathrm{~cm}^{-1}, 1516 \mathrm{~cm}^{-1}, 1440 \mathrm{~cm}^{-1}, 1216 \mathrm{~cm}^{-1}, 1175 \mathrm{~cm}^{-1}$, $814 \mathrm{~cm}^{-1}$. Elemental analysis: Calc. C 45. 22; H 2.0; N 4.00. Found: C 45.91; $\mathrm{H} 2.2 ; \mathrm{N} 3.8$

\section{Gelations}

\section{Using TEOS}

General procedure: The organometallic (see table 1 for details) was dissolved in $50 \mathrm{ml}$ of ethanol and then $\mathrm{Si}(\mathrm{OEt})_{4}(0.41 \mathrm{~g}-0.81 \mathrm{~g})$ followed by $0.141 \mathrm{~g}-0.745 \mathrm{~g}$ of nanopure water and $\mathrm{NH}_{4} \mathrm{~F} 0.0197 \mathrm{~g}$ as catalyst. The beaker was covered with Parafilm and the reaction mixture was left at room temperature until dryness. Photographs were taken at this stage. Further details for all the organometallic are shown in table 1.

Table 1 Preparative detail of the gels.

\begin{tabular}{|c|c|c|c|c|c|c|}
\hline Gelant agent & & $\mathrm{Si}\left(\mathrm{OC}_{2} \mathrm{H}_{5}\right)_{4}$ & & \multicolumn{3}{|c|}{$\mathrm{N}_{3} \mathrm{P}_{3}\left\{\mathrm{NH}\left[\mathrm{CH}_{2}\right]_{3} \mathrm{Si}[\mathrm{OEt}]_{3}\right\}_{6}$} \\
\hline Organometllic & g complex & $\mathrm{g}$ Gelant & $\mathrm{g} \mathrm{H}_{2} \mathrm{O}^{\mathrm{a}}$ & g complex & g Gelant & $\mathrm{g} \mathrm{H}_{2} \mathrm{O}^{\mathrm{a}}$ \\
\hline$\left\{\mathrm{HOC}_{5} \mathrm{H}_{5} \mathrm{~N} \bullet \mathrm{Ti}[\mathrm{Cp}]_{2} \mathrm{Cl}\right\} \mathrm{PF}_{6}(\mathbf{1})$ & 0.096 & 0.408 & 0.141 & 0.1 & 2.253 & 0.71 \\
\hline$\left\{\mathrm{HOC}_{6} \mathrm{H}_{4} \mathrm{CH}_{2} \mathrm{CN} \bullet \mathrm{Ti}[\mathrm{Cp}]_{2} \mathrm{Cl}\right\} \mathrm{PF}_{6}(4)$ & 0.149 & 0.894 & 0.309 & 0.25 & 5.099 & 1.61 \\
\hline$\left\{\mathrm{HOC}_{5} \mathrm{H}_{5} \mathrm{~N} \bullet \mathrm{W}(\mathrm{CO})_{5}\right\}(\mathbf{2})$ & 0.438 & 2.182 & 0.754 & 0.1 & 2.448 & 0.77 \\
\hline$\left\{\mathrm{HOC}_{6} \mathrm{H}_{4} \mathrm{CH}_{2} \mathrm{CN} \bullet \mathrm{W}(\mathrm{CO})_{5}\right\}(\mathbf{5})$ & 0.175 & 0.811 & 0.276 & 0.1 & 2.239 & 0.71 \\
\hline$\left\{\mathrm{HOC}_{5} \mathrm{H}_{5} \mathrm{~N} \bullet \mathrm{Mo}(\mathrm{CO})_{5}\right\}(\mathbf{3})$ & 0.342 & 2.122 & 0.726 & 0.1 & 3.092 & 0.98 \\
\hline$\left\{\mathrm{HOC}_{6} \mathrm{H}_{4} \mathrm{CH}_{2} \mathrm{CN} \bullet \mathrm{Mo}(\mathrm{CO})_{5}\right\}(6)$ & 0.142 & 0.821 & 0.276 & 0.07 & 1.988 & 0.628 \\
\hline
\end{tabular}

${ }^{\mathrm{a}} \mathrm{H}_{2} \mathrm{O}$ Nanopure.

Using $\mathrm{N}_{3} \mathrm{P}_{3}\left\{\mathrm{NH}\left[\mathrm{CH}_{2}\right]_{3} \mathrm{Si}[\mathrm{OEt}]_{3}\right.$

To the respective organometallic (see details in table 1) dissolved in ethanol, in a beaker, $\mathrm{N}_{3} \mathrm{P}_{3}\left\{\mathrm{NH}\left[\mathrm{CH}_{2}\right]_{3} \mathrm{Si}[\mathrm{OEt}]_{3}\right\}_{6}$ was added followed by water and $\mathrm{NH}_{4} \mathrm{~F}$ according to amounts given in table 1 . The mixture was stirred until dryness after which photographs of the gels were taken.

\section{Pyrolysis of the gels}

Solid samples of the as prepared gels were ground to a powder and then placed into an alumina crucible. The alumina crucible containing the sample was inserted into the furnace. (Thermolyne 1400 oven) The temperature of the system was ramped to $300^{\circ} \mathrm{C}$ and then to $800^{\circ} \mathrm{C}$. Following thermal treatment, the samples were cooled to room temperatures over ca. $2 \mathrm{~h}$.

\section{Characterization}

IR spectra were recorded on an FT-IR Perkin-Elmer Spectrum BX II spectrophotometer. Magic Angle Spinning (MAS) Nuclear Magnetic Resonance (NMR) spectra were obtained using an Oxford wide bore $9.4 \mathrm{~T}$ magnet equipped with a Bruker Avance II console and employing a $4 \mathrm{~mm} \mathrm{H} / \mathrm{X}$ CPMAS probe. For all samples, ${ }^{1} \mathrm{H}-\mathrm{X}$ Cross Polarization (CP) experiments were acquired using a $\mathrm{CP}$ mixing time of $2 \mathrm{~ms}\left(\mathrm{X}\right.$ being ${ }^{13} \mathrm{C},{ }^{29} \mathrm{Si}$ and ${ }^{31} \mathrm{P}$ ). A strong ${ }^{1} \mathrm{H}$ decoupling during acquisition time was applied by using the two-pulse phase modulation (TPPM) scheme. Spectra were acquired at $20^{\circ} \mathrm{C}$ temperature controlled by a BRUKER BCU unit.

For ${ }^{13} \mathrm{C}$ experiments the spectral frequency was $100.577 \mathrm{MHz}$ and the NMR chemical shifts are externally referenced to adamantane (major peak positioned at $38.6 \mathrm{ppm}$ ). For ${ }^{29} \mathrm{Si}$ experiments spectral frequency was $79.46 \mathrm{MHz}$ and the NMR chemical shifts are externally referenced to DSS. For ${ }^{31} \mathrm{P}$ experiments spectral frequency was $161.923 \mathrm{MHz}$ and the NMR chemical shifts are externally referenced to ADP. X-ray diffraction (XRD) was carried out at room temperature on a Siemens D-5000 diffractometer with $\theta-2 \theta$ geometry. The
$\mathrm{XRD}$ data was collected using $\mathrm{Cu}-\mathrm{K} \alpha$ radiation ( $40 \mathrm{kV}$ and $30 \mathrm{~mA}$ ). Scanning electron microscopy (SEM) was performed on a SEM LEO 1420 VP, Oxford Instruments equipped with EDS. Transmission electron microscopy (TEM) was carried out on a JEOL SX100 TEM, on the finely powered samples were dispersed in isopropanol and dropped on a conventional carbon-coated copper grid dried under a lamp. Thermogravimetric analysis (TGA) and differential scanning calorimetry (DSC) measurements were performed on a Mettler TA 4000 instrument and Mettler DSC 300 differential scanning calorimeter, respectively.

\section{RESULTS AND DISCUSSIONS}

\section{Preparations of the organometallic precursors}

The complexes (1), (2) and (4) have been reported previously 25,28 . The complexes (3), (5) and (6) were prepared using standard method (see experimental part). The new compounds are brown or yellow solid insoluble in common organic solvent. IR spectra exhibits clearly the presence of the $\mathrm{M}(\mathrm{CO})_{5}$ moiety, $\mathrm{M}=\mathrm{Mo}$ and $\mathrm{W}$ moiety. IR bands at $1974 \mathrm{~cm}^{-1}$ and $1951 \mathrm{~cm}^{-1}$ for (3), a broad absorption between 1987-1880 $\mathrm{cm}^{-1}$ for (6) and a broad band at $1936 \mathrm{~cm}^{-1}$ for $(\mathbf{5})$ corresponding to $v(\mathrm{CO})$ vibrations were observed for the Mo and $\mathrm{W}$ derivatives. Additionally the expected $v(\mathrm{CN})$ band was observed for the complexes $(\mathbf{5})$ and $(\mathbf{6})^{31}$. For the pyridine complex $(\mathbf{3})$ the emergence of a band at $1635 \mathrm{~cm}^{-1}$ typical of coordination of pyridine ligand, was also observed 30. The $\mathrm{n}(\mathrm{OH})$ band for $(\mathbf{3}),(\mathbf{5})$ and $(\mathbf{6})$ was observed normally at $3435 \mathrm{~cm}^{-1}$, $3422 \mathrm{~cm}^{-1}$ and $3367 \mathrm{~cm}^{-1}$ although slightly shifted respect to that of free ligand.

\section{Preparations of the Gels}

Table 2 summarizes all the gels formed. In the symbol $\mathrm{G}^{(\mathrm{i})}(\mathrm{x})$, (i) means the gelator used ie. TEOS (1) or $\mathrm{N}_{3} \mathrm{P}_{3}\left\{\mathrm{NH}\left[\mathrm{CH}_{2}\right]_{3} \mathrm{Si}[\mathrm{OEt}]_{3}\right\}_{6}(\mathbf{2})$ and (x) represent the organometallic precursor used ie. $1-6$. 
Table 2 Gels, $\mathrm{G}^{(\mathrm{i})}(\mathrm{x})$ prepared using the sol-gel/pyrolysis method.

\begin{tabular}{|c|c|c|}
\hline Organometallic & $\mathbf{S i}(\mathbf{O E t})_{4}$ & $\mathbf{N}_{3} \mathbf{P}_{3}\left\{\mathbf{N H}\left[\mathbf{C H}_{2}\right]_{3} \mathbf{S i}[\mathbf{O E t}]_{3}\right\}_{6}$ \\
\hline$\left[\mathrm{HOC}_{5} \mathrm{H}_{4} \mathrm{~N} \cdot \mathrm{Cp}_{2} \mathrm{TiCl}\right]\left[\mathrm{PF}_{6}\right]$ & $\mathrm{G}^{(1)}(1)$ & $\mathrm{G}^{(2)}(1)$ \\
\hline $\mathrm{HOC}_{5} \mathrm{H}_{4} \mathrm{~N} \cdot \mathrm{W}(\mathrm{CO})_{5}$ & $\mathrm{G}^{(1)}(2)$ & $\mathrm{G}^{(2)}(2)$ \\
\hline $\mathrm{HOC}_{5} \mathrm{H}_{4} \mathrm{~N} \cdot \mathrm{Mo}(\mathrm{CO})_{5}$ & $\mathrm{G}^{(1)}(3)$ & $\mathrm{G}^{(2)}(3)$ \\
\hline$\left[\mathrm{HOC}_{6} \mathrm{H}_{4} \mathrm{CH}_{2} \mathrm{CN} \cdot \mathrm{Cp}_{2} \mathrm{TiCl}\right]\left[\mathrm{PF}_{6}\right]$ & $\mathrm{G}^{(1)}(4)$ & $\mathrm{G}^{(2)}(4)$ \\
\hline $\mathrm{HOC}_{6} \mathrm{H}_{4} \mathrm{CH}_{2} \mathrm{CN} \cdot \mathrm{W}(\mathrm{CO})_{5}$ & $\mathrm{G}^{(1)}(5)$ & $\mathrm{G}^{(2)}(5)$ \\
\hline $\mathrm{HOC}_{6} \mathrm{H}_{4} \mathrm{CH}_{2} \mathrm{CN} \cdot \mathrm{Mo}(\mathrm{CO})_{5}$ & $\mathrm{G}^{(1)}(6)$ & $\mathrm{G}^{(2)}(6)$ \\
\hline
\end{tabular}

Experimental details are given in experimental section. The gels adopt approximately the color of the organometallic precursor ie. orange for $G^{(1)}$ $(1), G^{(2)}(1)$ and $G^{(2)}(4)$, yellow for $G^{(1)}(2), G^{(1)}(5), G^{(2)}(2)$ and $G^{(2)}(5)$ and white for $G^{(1)}(4)$ and $G^{(1)}(1)$ and see electronic supplementary materials $\left(S_{1}\right)$. Additionally the ${ }^{29} \mathrm{Si}$ MAS NMR spectroscopy confirms the presence of $\mathrm{T}^{1}$ ($59.2 \mathrm{ppm}$ for $\left.\mathrm{G}^{(2)}(4)\right)$ and $\mathrm{T}^{2}\left(-68.38 \mathrm{ppm}\right.$ for $\left.\mathrm{G}^{(2)}(1)\right)$ structures corresponding to $\mathrm{R}-\mathrm{Si}(\mathrm{OSi})_{2} \mathrm{OH}$ and $\mathrm{R}-\mathrm{Si}(\mathrm{OSi})(\mathrm{OH})_{2}$ links in the gels typical of condensation of TEOS ${ }^{4}$. The presence of the organometallic inside the corresponding gel is evidenced by their ${ }^{13} \mathrm{C}$ MAS NMR which exhibits signals at $44 \mathrm{ppm}, 26.4$ ppm, $23 \mathrm{ppm}$ and $17 \mathrm{ppm}$ for $\left.\mathrm{G}^{(2)}(1)\right)$. Thus, a signal observed at $64 \mathrm{ppm}$ can be assigned to some uncondensed $\mathrm{Si}-\mathrm{O}-\mathrm{CH}_{2} \mathrm{CH}_{3}$ arising from TEOS. For the gelation with $\left\{\mathrm{N}_{3} \mathrm{P}_{3}\left\{\mathrm{NH}\left[\mathrm{CH}_{2}\right]_{3} \mathrm{Si}[\mathrm{OEt}]_{3}\right\}_{6} \mathrm{a}^{31} \mathrm{P} \mathrm{NMR}\right.$ signal at $22.89 \mathrm{ppm}$ typical of the $\mathrm{N}_{3} \mathrm{P}_{3}$ evidenced the presence the phosphazene ring in the matrix ${ }^{31}$. Further MAS NMR data for another representative compounds are given in supplementary materials $\mathrm{S}_{2}$.

Pyrolysis of the gels under air at $800^{\circ} \mathrm{C}$ affords solids with pyrolytic yields in the range of $14-64 \%$. XRD of the solids exhibits a broad peak around $2 \theta$ $=23^{\circ}$ which is characteristic of amorphous silica ${ }^{13}$. A representative XRD is showed for $G^{(1)}(1)$ in figure $2 a$. At the left the peaks values tabulated and present in the sample are also given.

In another case, the broad peak around $2 \theta=23^{\circ}$ masks the possible peaks corresponding to the presence of metal oxide or metal phosphate inside the silica matrix. However, in some cases some peaks characteristic of the titanium oxides mixtures $\mathrm{TiO}_{2} / \mathrm{Ti}_{3} \mathrm{O}_{5}$ were observed as shown in figure 2a, for the product from $\mathrm{G}^{(1)}(1)$. In some cases the typical peak at $2 \theta=6^{\circ}$ typical of lamellar silica was observed as shown in figure $2 \mathrm{~b}$ for the pyrolytic product from $\mathrm{G}^{(2)}(2)$. Table 3 summarizes the pyrolytic products identified by XRD.

Table 3 Summary of the pyrolytic products from precursors gels $\mathbf{G}^{(\mathbf{i})}(\mathbf{x})$.

\begin{tabular}{|c|c|c|c|}
\hline $\mathbf{G}^{(y)}(\mathbf{x})$ & Pyrolytic products & $\mathbf{G}^{(y)}(\mathbf{x})$ & Pyrolytic products \\
\hline$G^{(1)}(1)$ & $\begin{array}{l}\mathrm{Ti}_{3} \mathrm{O}_{5} \text { (ortorrombic) } \\
\mathrm{TiO}_{2} \text { (anatasa) }\end{array}$ & $G^{(2)}(1)$ & $\begin{array}{c}\mathrm{SiP}_{2} \mathrm{O}_{7} \text { (monoclinic) } \\
\mathrm{SiO}_{2} \text { (tetragonal) } \\
\mathrm{Ti}\left(\mathrm{PO}_{3}\right)_{3} \text { (monoclinic) }\end{array}$ \\
\hline$G^{(1)}(2)$ & $\begin{array}{l}\mathrm{PW}_{8} \mathrm{O} \text { (monoclinic) } \\
\mathrm{SiO}_{2} \text { (tetragonal) } \\
\mathrm{WO}_{3} \text { (tetragonal) }\end{array}$ & $G^{(2)}(2)$ & $\begin{array}{c}\mathrm{P}_{4} \mathrm{O}_{7} \text { (monoclinic) } \\
\mathrm{SiO}_{2} \text { (monoclinic) } \\
\mathrm{SiP}_{2} \mathrm{O}_{7} \text { (monoclinic) } \\
\mathrm{W}_{32} \mathrm{O}_{84} \text { (monoclinic) }\end{array}$ \\
\hline$G^{(1)}(3)$ & & $G^{(2)}(3)$ & $\begin{array}{l}\mathrm{Mo}_{4} \mathrm{O}_{11} \text { (monoclinic) } \\
\mathrm{SiP}_{2} \mathrm{O}_{7} \text { (monoclinic) } \\
\mathrm{SiO}_{2} \text { (monoclinic) }\end{array}$ \\
\hline$G^{(1)}(4)$ & $\begin{array}{l}\mathrm{Ti}_{0,784} \mathrm{O}_{2} \text { (tetragonal) } \\
\mathrm{Si}_{0,98} \mathrm{O}_{2} \text { (cubic) }\end{array}$ & $G^{(2)}(4)$ & $\begin{array}{l}\mathrm{SiO}_{2} \text { (rómbic) } \\
\mathrm{TiO}_{2} \text { (anatasa) }\end{array}$ \\
\hline$G^{(1)}(5)$ & $\begin{array}{l}\mathrm{SiO}_{2} \text { (tetragonal) } \\
\mathrm{WO}_{3} \text { (tetragonal) }\end{array}$ & $G^{(2)}(5)$ & $\begin{array}{c}\mathrm{SiP}_{2} \mathrm{O}_{7} \text { (monoclinic) } \\
\left.\mathrm{SiO}_{2} \text { (triclinic }\right) \\
\mathrm{P}_{4} \mathrm{O}_{7} \text { (monoclinic) } \\
\left.\mathrm{W}_{32} \mathrm{O}_{84} \text { (ortorrómbic }\right)\end{array}$ \\
\hline$G^{(1)}(6)$ & $\begin{array}{c}\mathrm{SiO}_{2} \text { (tetragonal) } \\
\mathrm{Mo}_{9} \mathrm{O}_{26} \text { (monoclinic) }\end{array}$ & $G^{(2)}(6)$ & $\begin{array}{c}\mathrm{Mo}_{9} \mathrm{O}_{26} \text { (monoclinic) } \\
\mathrm{SiP}_{2} \mathrm{O}_{7} \text { (monoclinic) } \\
\mathrm{P}_{4} \mathrm{O}_{7} \text { (monoclinic) } \\
\mathrm{Mo}_{2}\left(\mathrm{P}_{4} \mathrm{Si}_{4} \mathrm{O}_{23}\right) \text { (triclinic) }\end{array}$ \\
\hline
\end{tabular}

Clearly when the gelator is $\left\{\mathrm{N}_{3} \mathrm{P}_{3}\left\{\mathrm{NH}\left[\mathrm{CH}_{2}\right]_{3} \mathrm{Si}[\mathrm{OEt}]_{3}\right\}_{6}\right.$ appears the respective metal phosphate and pyrophosphates as pyrolytic products, which are absent when the gelator is TEOS ; in this case only the metal oxides are obtained. An exception is for $\mathrm{G}^{(1)}(2)$ where the $\mathrm{PW}_{8} \mathrm{O}$ product can arise from the $\mathrm{PF}_{6}$ anion of the precursor (1).

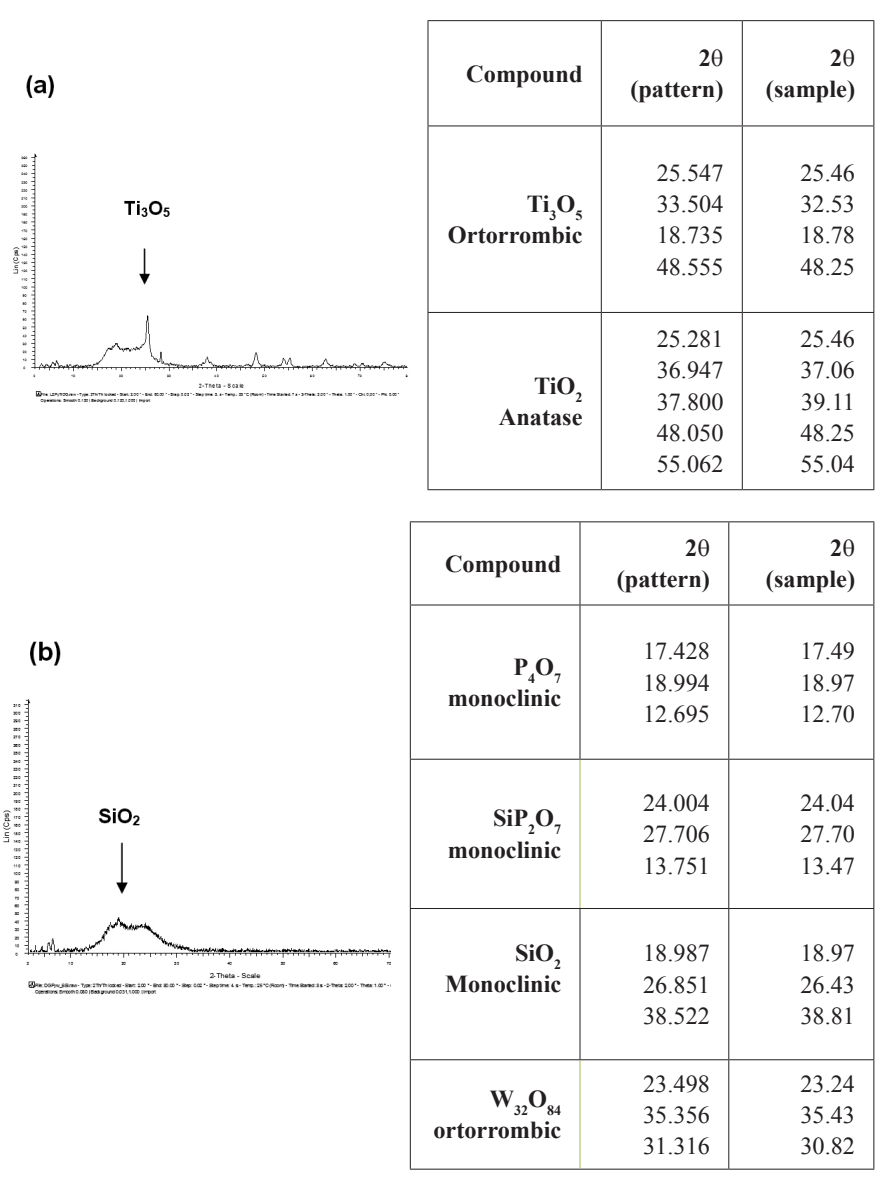

Fig. 2 Representative X-Ray diffraction pattern powder of the pyrolytic product from the gel $G^{(1)}(1)$, (a) and from $G^{(2)}(2)$ (b). On the right of each pattern, a detailed comparison of the observed lines with those of the reported are showed.

IR spectra of the pyrolyzed gels exhibits a very simple pattern with an intense band around $1100 \mathrm{~cm}^{-1}$ and a less intense one at $800 \mathrm{~cm}^{-1}$, which can be assigned to $\mathrm{Si}-\mathrm{O}, \mathrm{Si}-\mathrm{O}-\mathrm{Si}$ vibrations of the silica ${ }^{33-35}$. A medium intensity band around $470 \mathrm{~cm}^{-1}$ is assigned to a Si-O-Si rocking modes. In the spectra of gels derived from the gelator $\mathrm{N}_{3} \mathrm{P}_{3}\left\{\mathrm{NH}\left[\mathrm{CH}_{2}\right]_{3} \mathrm{Si}[\mathrm{OEt}]_{3}\right\}_{6}$ the band around $1100 \mathrm{~cm}^{-1}$ appears broad due to the presence of $\mathrm{P}=\mathrm{O}$ bands arising from metal pyrophosphates and phosphates ${ }^{36}$. Additionally, a weak band around $1640 \mathrm{~cm}^{-1}$ was assigned to an overtone of the $\mathrm{O}-\mathrm{H}$ stretching band of the residual $\mathrm{Si}-\mathrm{OH}$ bonds ${ }^{33-35}$. This appears in the range of $4320-3420 \mathrm{~cm}^{-1}$. A representative IR spectrum is give in figure 3 for $\mathrm{G}^{(1)}(5)$ and $\mathrm{G}^{(2)}(1)$.

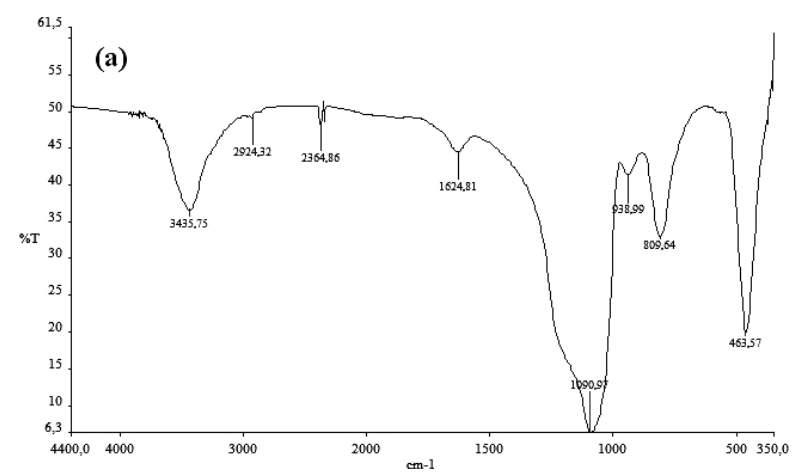




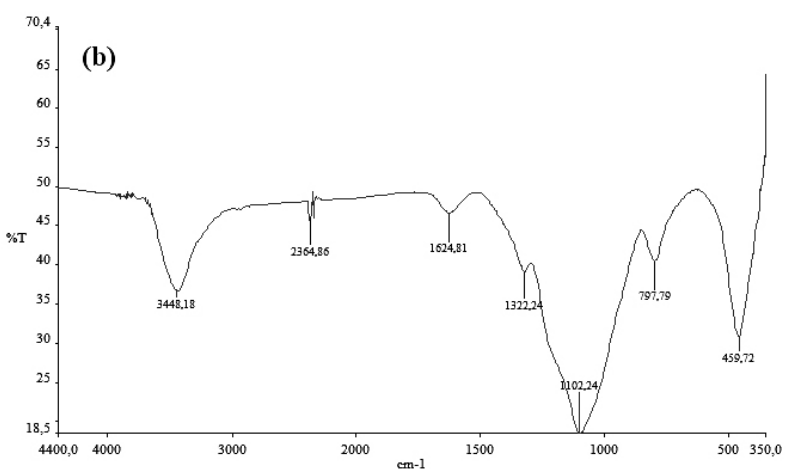

Fig. 3 Representative IR spectra $(\mathrm{KBr})$ of the pyrolytic power product from precursor for $\mathrm{G}^{(1)}(5)$ (a) and $\mathrm{G}^{(2)}(1)$ (b).

4.

The morphology of the products observed by SEM is summarized in table

Table 4 Main morphology of the products obtained by SEM.

\begin{tabular}{|c|c|c|}
\hline Organometallic & $\mathbf{S i}(\mathbf{O E t})_{4}$ & $\mathbf{N}_{3} \mathbf{P}_{3}\left\{\mathbf{N H}\left[\mathbf{C H}_{2}\right]_{3} \mathbf{S i}[\mathbf{O E t}]_{3}\right\}_{6}$ \\
\hline$\left[\mathrm{HOC}_{5} \mathrm{H}_{4} \mathrm{~N} \cdot \mathrm{CpTiCl}\right]\left[\mathrm{PF}_{6}\right]$ & Porous & Foam \\
\hline $\mathrm{HOC}_{5} \mathrm{H}_{4} \mathrm{~N} \cdot \mathrm{W}(\mathrm{CO})_{5}$ & Laminar & $\begin{array}{c}\text { Laminar/Inner, porous } \\
\text { Porous }\end{array}$ \\
\hline $\mathrm{HOC}_{5} \mathrm{H}_{4} \mathrm{~N} \cdot \mathrm{Mo}(\mathrm{CO})_{5}$ & ------ & Laminar \\
\hline$\left[\mathrm{HOC}_{6} \mathrm{H}_{4} \mathrm{CH}_{2} \mathrm{CNCpTiCl}\right]\left[\mathrm{PF}_{6}\right]$ & Dense & Laminar \\
\hline $\mathrm{HOC}_{6} \mathrm{H}_{4} \mathrm{CH}_{2} \mathrm{CN} \cdot \mathrm{W}(\mathrm{CO})_{5}$ & Dense & Laminar \\
\hline $\mathrm{HOC}_{6} \mathrm{H}_{4} \mathrm{CH}_{2} \mathrm{CN} \cdot \mathrm{Mo}(\mathrm{CO})_{5}$ & Porous & Laminar \\
\hline
\end{tabular}
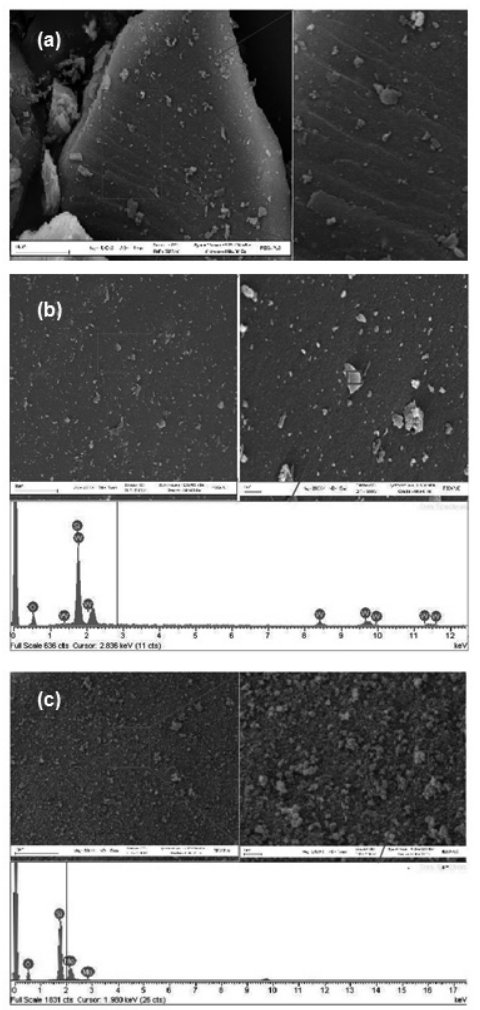

Fig. 4. SEM image of the pyrolytics products from from $\mathrm{G}(2)(2)$ (a), G(1) (5) (b) and $G(1)(6)$ (c) illustrating the morphologies laminar, dense and porous. respectively. For $G(1)(5)$ below fig. (b) and for $G(1)(6)$ below fig.(c) their respective EDX are also showed.
The laminar morphology in silica has been observed in other sol-gel products ${ }^{32}$. In the laminar morphologies, almost always the typical peak at $2 \theta=6^{\circ}$ typical of lamellar silica was observed. It is interesting to observe that the laminar morphology is obtained mainly when the precursor $\mathrm{N}_{3} \mathrm{P}_{3}\left\{\mathrm{NH}\left[\mathrm{CH}_{2}\right]_{3} \mathrm{Si}[\mathrm{OEt}]_{3}\right\}_{6}$ is used as gelator, see figure 4 . This can be owing to the self-organization induced by the $\mathrm{N}_{3} \mathrm{P}_{3}$ moiety. EDS analysis showing the expected presence of the corresponding elements are displayed on top of figure $5 b, 5$ c for $\mathrm{G}^{(1)}(5)$ and $\mathrm{G}^{(1)}(6)$ respectively.

TEM images exhibited different shapes and sizes. For $\mathrm{G}^{(1)}(1)$ the typical nearly circular nanoparticles of mainly $\mathrm{Ti}_{3} \mathrm{O}_{5}$ were observed as shown in figure 5a.The most gray back corresponds to $\mathrm{SiO}_{2}$
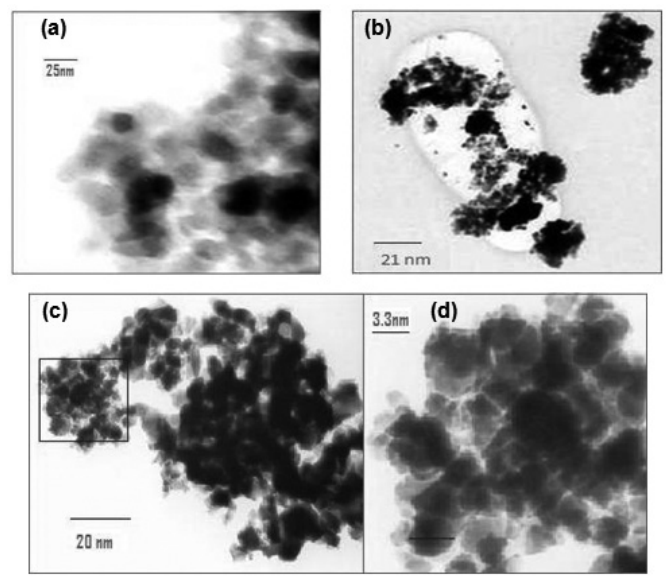

Fig. 5 TEM image of the pyrolytic products from precursors $G^{(1)}(1)$ (a), $\mathrm{G}^{(1)}(4)(b)$ and $\mathrm{G}^{(1)}(6)(\mathrm{c})$.The image (d) is a magnification of the squared marked zone of (c).

Similar TEM of metallic nanoparticles inside $\mathrm{SiO}_{2}$ have been reported $13,16,21,23$. Some more irregular shapes were observed for $\mathrm{G}^{(1)}(4)$, figure $5 \mathrm{~b}$ (titanium oxides tetragonal phase mainly) and for $\mathrm{G}^{(1)}(6)$ (two mainly phases, molybdenum oxides and $\mathrm{SiP}_{2} \mathrm{O}_{7}$ ), see figure $5 \mathrm{c}$. Similar image TEM have been reported for other metallic nanoparticles included inside $\mathrm{SiO}_{2}^{6,14}$. Figure $5 \mathrm{~d}$ show a magnification of the square zone exhibited in figure $5 \mathrm{c}$.The line below the image of figure $5 \mathrm{~d}$ show a particle with a mean size of $3.5 \mathrm{~nm}$.

Interestingly for the pyrolytic product from $\mathrm{G}^{(2)}(5)$ (tungsten oxides and $\mathrm{SiP}_{2} \mathrm{O}_{7}$ phases mainly) a nanocable was observed as shown in figure 6. Comparing with similar TEM of nanocables of metallic, metal oxides nanowires coated with amorphous silica ${ }^{37,38}$, the TEM observed for $\mathrm{G}^{(2)}(5)$ can be suggested to be nanowires of $\mathrm{WO} / \mathrm{SiP}_{2} \mathrm{O}_{7}$ coated with amorphous silica. Also metal nanotubes encapsulated in $\mathrm{ZrO}_{2}$ exhibit similar TEM images ${ }^{39}$.
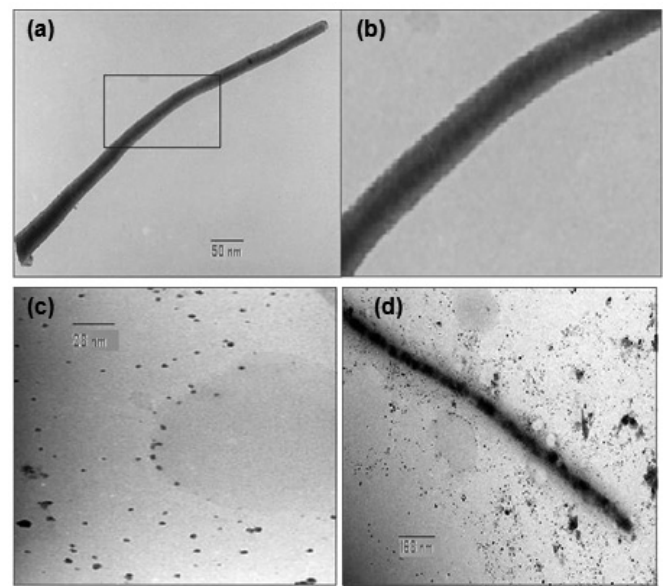

Fig. 6 Nanocables observed from pyrolysis of $G^{(2)}(5)(a)$, (b) and $G^{(2)}(1) c$, d. The image (b) is a magnification of (a). Images (c) and (d) are two different zones of the same sample, see text. 
For $\mathrm{G}^{(2)}(1)$ two different zones were observed, one with small nearly circular nanoparticles and another with nanotubes. The most dark structures probably are $\mathrm{Ti}\left(\mathrm{PO}_{3}\right)_{3}$ The observed TEM image 6d is similar to the one decorated in nanowires nanostructures ${ }^{39-41}$. For instance, iron oxides nanoparticles inside carbon nanotubes ${ }^{39,40}$ and $\mathrm{SiO}_{2}$-coated CdTe nanowires exhibit similar TEM images ${ }^{41}$. For another pyrolyzed gel and as observed normally in metal inside, $\mathrm{SiO}_{2}$ gels $^{19}$, agglomerates were observed by TEM see supplementary materials $\mathrm{S}_{3}$.

Evidence of the mechanism of formation of the metallic nanostructures in the silica matrix, from gels precursors, was obtained by TG/DSC analysis. Important differences were observed in the TG patterns either being the gel either was obtained by using TEOS or $\mathrm{N}_{3} \mathrm{P}_{3}\left\{\mathrm{NH}\left[\mathrm{CH}_{2}\right]_{3} \mathrm{Si}[\mathrm{OEt}]_{3}\right\}_{6}$ as gel precursor. For the former two main weight losses in contrast to when using the phosphazene-Si precursor, four weight losses were observed. In Supplementary material $\mathrm{S}$ representative curves TG/DSC for $\mathrm{G}^{(1)}(1)$, and $\mathrm{G}^{(2)}$ (1) are shown. For the $G^{(1)}(i)$ series the first weight loss was attributed to the residual water molecules and/or removal of solvent molecules. The second weight may be assigned to a loss of water from condensation of residual Si$\mathrm{OH}$ units. An appreciable mass loss is detectable between 300 and $600{ }^{\circ} \mathrm{C}$, which correspond to strong exothermic peaks in the DTA curves. This is due to the combustion of organic which arises from another residual $\mathrm{CH}_{3} \mathrm{CH}_{2}$ of TEOS and/or the organic groups of the organometallic compound included in the silica.

For the series $\mathrm{G}^{(2)}(\mathrm{i})$ a first weight loss around $100{ }^{\circ} \mathrm{C}$ can be attributed to a loss of solvent and/or water molecules consistently with the endothermic peak around this temperature observed in their DSC curve. The expected combustion of the organic matter was observed in several steps starting around $300{ }^{\circ} \mathrm{C}$ with strong loss around $400{ }^{\circ} \mathrm{C}$ and $500{ }^{\circ} \mathrm{C}$ in agreement with their DSC showing exothermic peaks at these temperatures. This thermogravimetric behavior is similar and typical of those of another metal/organometallic/ $\mathrm{SiO}_{2}$ system ${ }^{14,19,42,43}$.

\section{4.-General discussion}

As discussed previously (see introduction section) few examples of organometallic compounds included into $\mathrm{SiO}_{2}$ have been reported. Also few report of metallic oxides incorporated inside amorphous $\mathrm{SiO}_{2}$ have appeared. The most of these last type of compounds arise from catalyst system of the type metal oxide $/ \mathrm{SiO}_{2}{ }^{44-46}$ or mixture of metal oxides systems (metal oxide) ${ }^{1}$ (metal oxide $)^{2} / \mathrm{SiO}_{2}{ }^{47,48}$

In comparing TEOS and $\mathrm{N}_{3} \mathrm{P}_{3}\left\{\mathrm{NH}\left[\mathrm{CH}_{2}\right]_{3} \mathrm{Si}[\mathrm{OEt}]_{3}\right\}_{6}$ as gelators some conclusion emerge. As can be expected in agreement with our previous results ${ }^{25-29}$ when the gelator was $\mathrm{N}_{3} \mathrm{P}_{3}\left\{\mathrm{NH}\left[\mathrm{CH}_{2}\right]_{3} \mathrm{Si}[\mathrm{OEt}]_{3}\right\}_{6}$ metal phosphates and pyrophosphates were obtained. Also this latter as a new gelator agent ${ }^{49}$ induce materials with mainly laminar morphologies.

The actual technological application usually requires the use of metallic nanoparticles ${ }^{50-52}$ in solid-sate devices. This in turn, requires the development of adequate methods for the solid-state preparation of nanoparticles. Thus this is one of the main challenges of the nanochemistry. Then, the here presented method, can be a useful and general method to obtain metal phosphates, pyrophosphate and metal oxide inside amorphous silica, materials with potential technological application in solid-state device ${ }^{50-52}$.

\section{CONCLUSIONS}

The organometallic MLn $=\left[\mathrm{HOC}_{5} \mathrm{H}_{4} \mathrm{~N} \cdot \mathrm{Cp}_{2} \mathrm{TiCl}\right]\left[\mathrm{PF} \mathrm{F}_{6}\right]$ (1), $\mathrm{HOC}_{5} \mathrm{H}_{4} \mathrm{~N} \cdot \mathrm{W}(\mathrm{CO})_{5}(2), \mathrm{HOC}_{5} \mathrm{H}_{4} \mathrm{~N} \cdot \mathrm{Mo}(\mathrm{CO})_{5}(3),\left[\mathrm{HOC}_{6} \mathrm{H}_{4} \mathrm{CH}_{2} \mathrm{CN} \cdot \mathrm{Cp}_{2} \mathrm{TiCl}\right]$ $\left[\mathrm{PF}_{6}\right](4), \mathrm{HOC}_{6} \mathrm{H}_{4} \mathrm{CH}_{2} \mathrm{CN} \cdot \mathrm{W}(\mathrm{CO})_{5}(5)$ and $\mathrm{HOC}_{6} \mathrm{H}_{4} \mathrm{CH}_{2} \mathrm{CN} \cdot \mathrm{Mo}(\mathrm{CO})_{5}(6)$ were successfully included into amorphous $\mathrm{SiO}_{2}$ using the gelator precursor TEOS and $\mathrm{N}_{3} \mathrm{P}_{3}\left\{\mathrm{NH}\left[\mathrm{CH}_{2}\right]_{3} \mathrm{Si}[\mathrm{OEt}]_{3}\right\}_{6}$. The products, gels of composition $(\mathrm{MLn})\left(\mathrm{SiO}_{2}\right)_{1}$, after pyrolysis afford mainly laminar products using the $\mathrm{N}_{3} \mathrm{P}_{3}\left\{\mathrm{NH}\left[\mathrm{CH}_{2}\right]_{3} \mathrm{Si}[\mathrm{OEt}]_{3}\right\}_{6}$ as gelator and either dense or porous using TEOS as gelator. Diverse shapes as nanocables and nanowires of $\mathrm{WO} /$ $\mathrm{SiP}_{2} \mathrm{O}_{7}$ and $\mathrm{Ti}\left(\mathrm{PO}_{3}\right)_{3}$ probably coated with amorphous silica were observed. The method can be a new easy and simple way to obtain nanostructured metallic containing inside amorphous $\mathrm{SiO}_{2}$. In contrast when the gelator was TEOS and the organometallic does not contain any phosphorus atoms, the metal oxide inside silica was obtained. The sililated cyclotriphosphazene $\mathrm{N}_{3} \mathrm{P}_{3}\left\{\mathrm{NH}\left[\mathrm{CH}_{2}\right]_{3} \mathrm{Si}[\mathrm{OEt}]_{3}\right\}_{6}$ as a new gelator, induce the formation of mainly laminar $\mathrm{SiO}_{2}$ matrix.

\section{ACKNOWLEDGMENT}

To project Fondecyt 1085011 for financial support

\section{REFERENCES}

1. M Ebelmen Ann Chim Phys 16, 129,(1846)

2. C. J. Brinker, G. Scherrer Sol-Gel Science; Academic Press,(2002), London.

3. K. J. Shea, D.A. Loy M.R.S. Bull 26, 368,(2001).

4. K. J. Shea, D.A. Loy, O Webster, J Am Chem Soc 114, 6700, (1992).

5. D. A. Loy, K.J. Shea, Chem Rev 95, 1431, (1995).

6. K, Moon, K. J. Shea, J. Am. Chem. Soc. 116, 9052, (1994).

7. G. Cerveau, R.P. Corriu, C. Lepeytre, Chem Mater 9, 2561 (1997).

8. C.T. Kresge, M.E. Leonowics, W.J. Roth, J.C. Vartuli, J.S. Beck Nature 359, 710(1992).

9. J. S. Beck, J.C. Vartuli, W.J. Roth, M.E. Leonowics, C.T. Kresge, K.D Schmit, C.T. Chu, D.H. Olson, E.W. Sheppard, S.B. McCullen, J.B. Higginns, J.L. Schlenker, J Am Chem Soc 114, 10834, (1992).

10. K. Moller, T. Bein, Chem Mater 10, 2950,(1998).

11. J. V. Walker, M. Morey, H. Carlsson, A. Davidson, G.D. Stucky, A. Butler, J Am Chem Soc 119, 6921,(1997).

12. R. Anwander, Chem Mater 13, 4419,(2001).

13. F. Del Monte, M.P. Morales, D. Levy, A. Fernandez, M. Ocaña, A. Roig, E. Molins, K.O. Grady, C.J. Serna, Langmuir 13, 3627(1997).

14. C. Cannas, M.F. Casula, G. Concas, A. Corrias, D. Gatteschi, A. Falqui, A. Musinu, C. Sangregorio, G. J. Spano, Chem Mater 11, 3180 (2001).

15. W. Nie, G. Boulon, C. Mai, C. Esnouf, X. Runjuan, J. Zarzycki, Chem Mater, 4, 216 (1992).

16. G. De, J. Sol Gel Sci Tech 11, 289,(1998).

17. S Sakka, H. Kozuka, J Sol Gel Sci Tech 13, 701 (1998)

18. E. R. Leite, N.L. Carreño, E, Longo, F.M. Pontes, A. Barison, A.G. Ferreira, Y. Maniette, J.Á. Varela, Chem Mater 14, 3722 (2002).

19. K. L. Fujdala, T. Don Tilley Chem Mater, 13, 1817, (2001).

20. V. S. Gurin, A.A. Alexeenko, V.B. Prakapenka, D.L. Kovalenko, K.V. Yumashev, P.V. Prokoshin, J Mater Science Mat In Elect, 14, 333 (2003).

21. B. Breitscheidel, J. Zieder, U. Schubert, Chem Mater 3, 559(1991).

22 Y. Yin, Y. Lu, Y. Sun, Y. Xia, Nano Lett 2, 427,(2002).

23. C. M. Lukehart, S.B. Milne, Chem Mater, 10: 903, (1998).

24. E. Lindner, A. Jager, T. Schneller and H.A. Mayer, Chem Mater 9, 81, (1997).

25. C, Díaz, M.L. Valenzuela, Macromolecules 39, 103,(2006).

26. C. Díaz, M.L. Valenzuela, S. Ushak, V. Lavayen, C. O’Dwyer, $J$ Nanoscience and Nanotechnology 9, 1825 (2009).

27. J. Jiménez, A. Laguna, J. Antonio Sanz, C. Díaz, M.L. Valenzuela, P.G. Jones Chem Eur J, 15,13509,(2009).

28. Díaz C, Valenzuela ML, Zuñiga, L, O’Dwyer C, J Inorg Organomet Polym, 19, 507 (2009).

29. C. Díaz, M.L. Valenzuela, D. Bravo, V. Lavayen, C. O’Dwyer, Inorganic Chemistry 47, 11561, (2008).

30. G. A. Carriedo, F.J. Garcia-Alonso, J.L. Garcia Alvarez, C. Díaz, N. Yutronic, Polyhedron 21, 2587, (2000).

31. C. Diaz, M. Barbosa, Z. Godoy, Polyhedron 23,1027, (2004).

32. R. K. Donato M.V. Migliorini, M.A. Benvegnu, M.P. Strake, M.A. Gelesky, F.A. Pavan, C.M.L. Screkker, E.V. Benvenutti, J. Dupont, H.S. Schrekker, J. Sol Gel Sci Technnol 49, 71,(2009).

33. Y. Zhang, Y. Li, G. Li, H. Huang, H.L.W. Chan, W.A. Daoud, J.H. Xin and L. Li Chem Mater 19,193, (2007).

34. T. A. Crowley, K.J. Ziegler, M. Lyons, D. Erts, H. Olin, M.A. Morris and J. D Holmes Chem Mater 15, 3518, (2003).

35. X. Ji, Q. Hu, J.E. Hampsey, H. Qiu, .L Gao, J. He, Y. Lu, Chem Mater 18 2265, (2006).

36. S. Dire, G. Facchin, F.R. Ceccato, L. Guarino, A. Sassi, M. Gleria $J$. Inorg. Organome. Polym. 12, 59, (2002).

37. Y. Yin; Y. Lu, Y. Sun, Y. Xia, Nano Lett 2,427, (2002).

38. J. Bao, D. Xu, Q. Zhou, Z. Xu, Chem Mater 14, 4709,(2002).

39. B. K. Pradhan, T. Toba, T. Kyotani, A. Tomit, Chem Mater 10, 2510, (1998).

40. G. Kormeva, H. Ye, Y. Gogotsi, D. Halverson, D. Friedman, J.C., Bradley, K.G. Kornev Nano Lett 5, 879, (2005).

41. Y. Wang, Z. Tang, X. Liang, L.M. Liz-Marzan, N.L. Kotov, Nano Let, 4 $225,(2004)$.

42. U. Schubert, S. Amberg-Schwag, B. Breitscheidel, Chem Mater, 3, 576,(1989).

43. L. Bronstein, E. Krämer, B. Berton, Ch. Burger, S. Forster, M. Antonietti, Chem Mater 11,1402, (1999). 
44. S. M. Lomnicki, H. Wu, S. N. Osborne, J. M. Pruett, R.L. McCartey, E. Poliakoff, B. Dellinger, Material Science and Engineering B 175, 136 (2010)

45. T. Uemura, D.Hiramatsu, K. Yoshida, S. Isoda, S. Kitagawa J Am Chem Soc 130, 9216, (2008).

46. S. Polarz, F.Neues, M.W.E. van den Berg, W. Grunert, L. Khodeir $J$ Am Chem Soc 127, 12028, (2005).

47. W. C. Vining, J. Strunk, A. T. Bell J. Catal. 285, 160 (2012)

48. B. Yan, Y. Zhao, Q-P, Li J. Photochem. Photobiol. A: Chem. 222, 351 (2011)
49. C. Diaz, M.L Valenzuela, N. Yutronic, P. Aguirre, J. Chil. Chem. Soc. 55, 415 (2010).

50. G. Walters, I. P. Parkin, J. Chem Mater 19, 574, (2009).

51. G. B.Khomutov, V.V. Kislov, M. N. Antipirina, R.V.Gainutdinov, S. P.Gubin, A.Yy Obydenov, S.A. Pavlov, A.A. Rakhnyanskaya, A.N. Sergeev-Cherenkov, E. S. Soldatov, D.B. Suyatin, A.L. Toltikhina, A. S. Trifonov, T.V.Yurova, Microelectronic Engineering, 69 373, (2003).

52. E. C. Walter, K. Ng, M.P. Zach, R.M. Penner, F.Favier Microelectronic Engineering 61, 555, (2002). 


\section{SUPPLEMENTARY MATERIALS TO: \\ JOURNAL OF THE CHILEAN CHEMICAL SOCIETY}

\section{DÍAZ ${ }^{a}$, M.L. VALENZUELA ${ }^{b}$, D. GARRIDO ${ }^{a}$ AND P. AGUIRRE ${ }^{c}$}

Incorporation of Organometallic compounds into silica: useful precursors to metallic nanostructured materials

$\mathrm{S}_{1}$

Photographie showing the color of some of the as synthesized gels : (I) $\mathbf{G}^{(1)}$ (2), (II) $G^{(2)}(6)$ and (III) $G^{(2)}(5)$

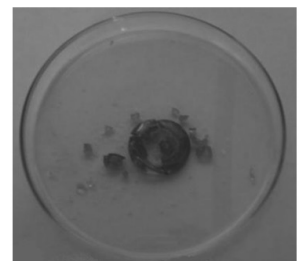

(I)

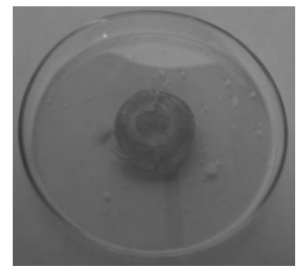

(II)

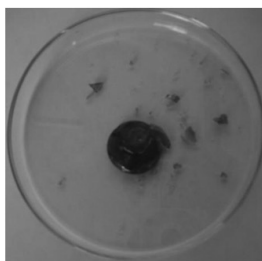

(III)
$\mathrm{S}_{2}$

${ }^{29}$ Si- MAS- NMR for some representative $G^{(\mathrm{I})}(\mathrm{x})$ gels

$\begin{array}{lcc}\text { Gel } & { }^{29} \mathrm{Si} & (\mathbf{p p m}) \\ \mathbf{G}^{(1)}(5) & \mathbf{5 9 . 2} & \mathbf{6 8 . 3 8} \\ \mathbf{G}^{(2)}(4) & \mathbf{5 9 . 7 4} & \mathbf{6 8 . 1 7} \\ \mathbf{G}^{(1)}(2) & \mathbf{5 9 . 6 2} & \mathbf{6 9 . 5 6} \\ \mathbf{G}^{(2)}(1) & \mathbf{5 9 . 5 2} & \mathbf{6 8 . 1 0} \\ \mathbf{G}^{(2)}(\mathbf{6}) & \mathbf{5 9 . 5 4} & \mathbf{6 8 . 3 5}\end{array}$

$S_{3}$ TEM images for another pyrolytic products

1) TEM from precursor $G^{(1)}(2)$.

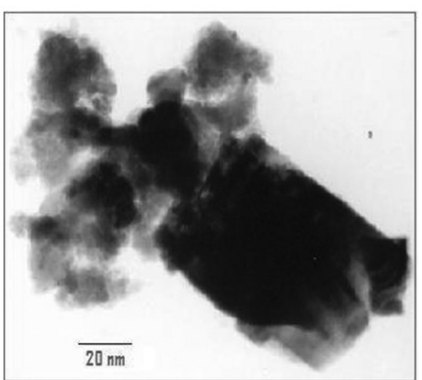

2) TEM from precursor de $G^{(2)}(2)$.

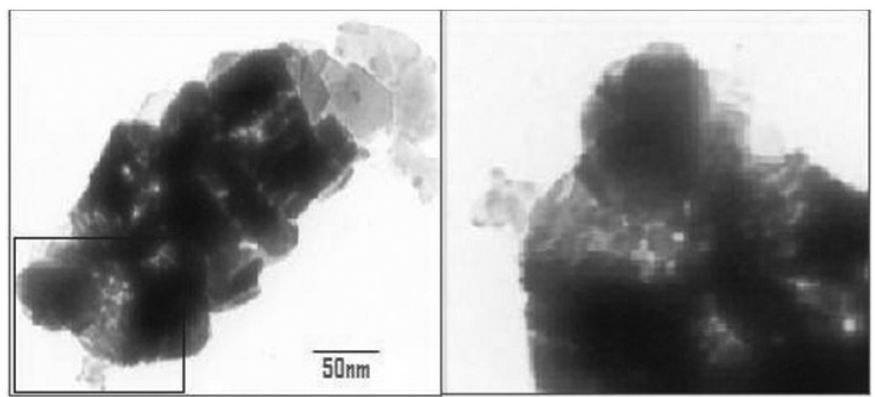

3) TEM from precursor $G^{(2)}(3)$.

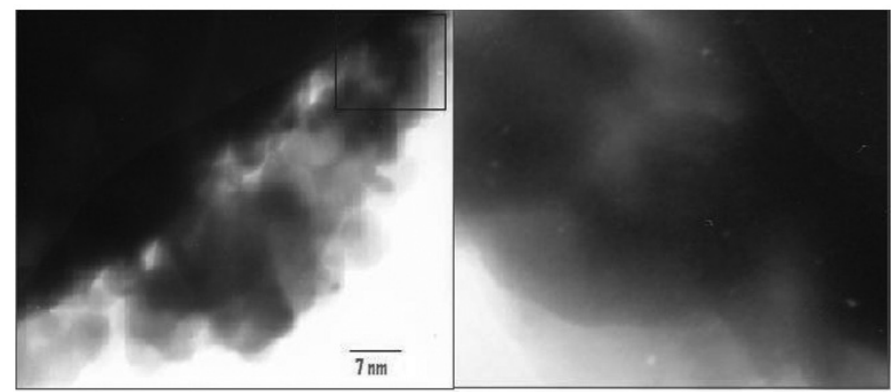

4) TEM from precursor $G^{(2)}(4)$.

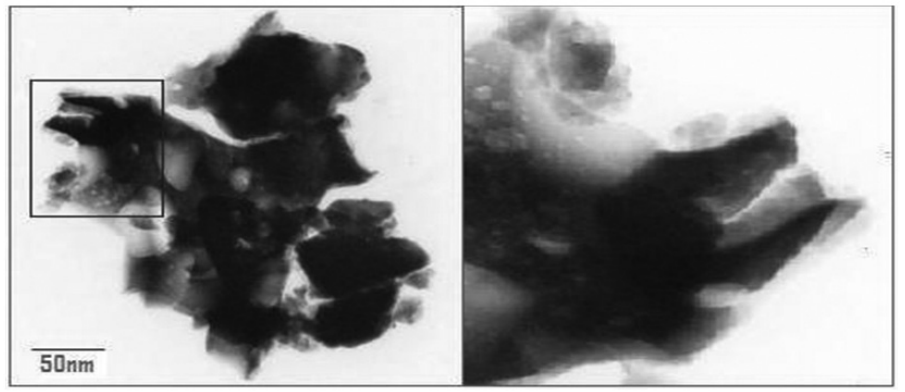

$\mathrm{S}_{4}$ Some TG and DSC data for some representative $G^{(1)}(x)$ gels TG and DSC curves of $G^{(1)}(1)$ and $G^{(2)}(1)$

TG of $G^{(1)}(1)$

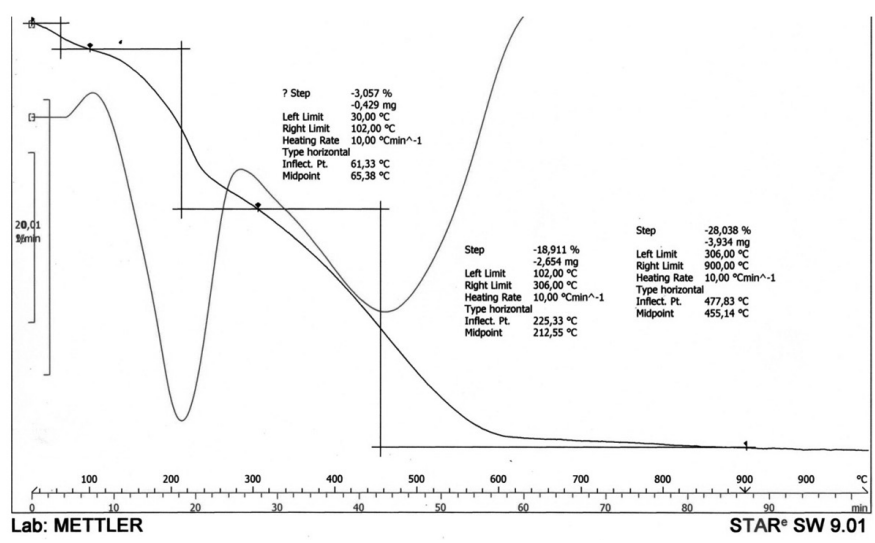


DSC of $G^{(1)}(1)$

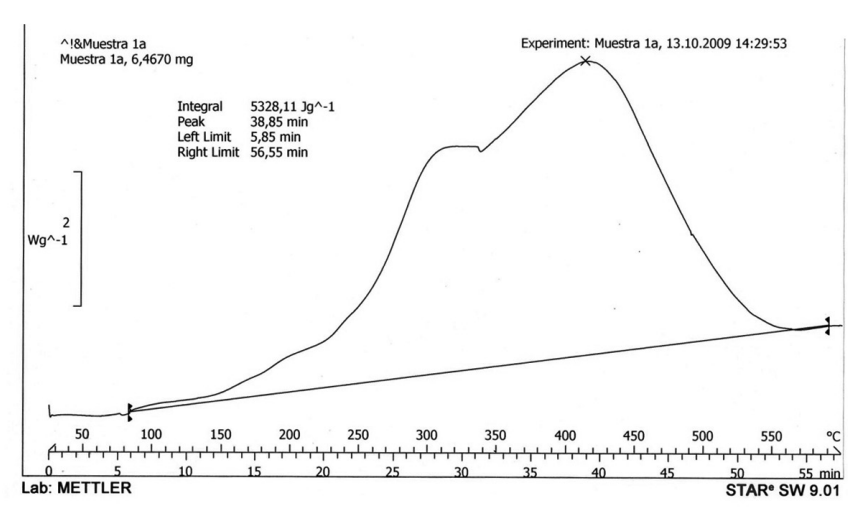

\section{DSC $G^{(2)}(1)$}

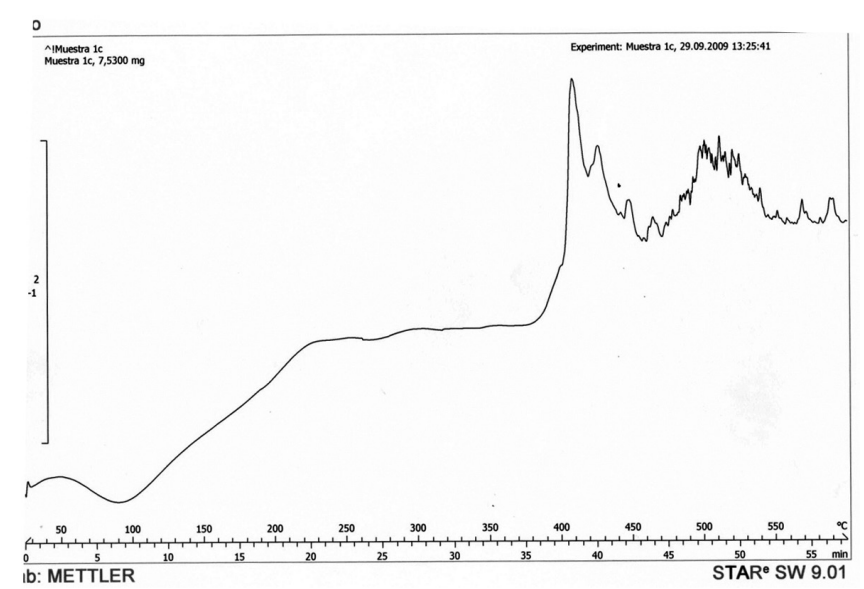

\section{TG of $G^{(2)}(1)$}

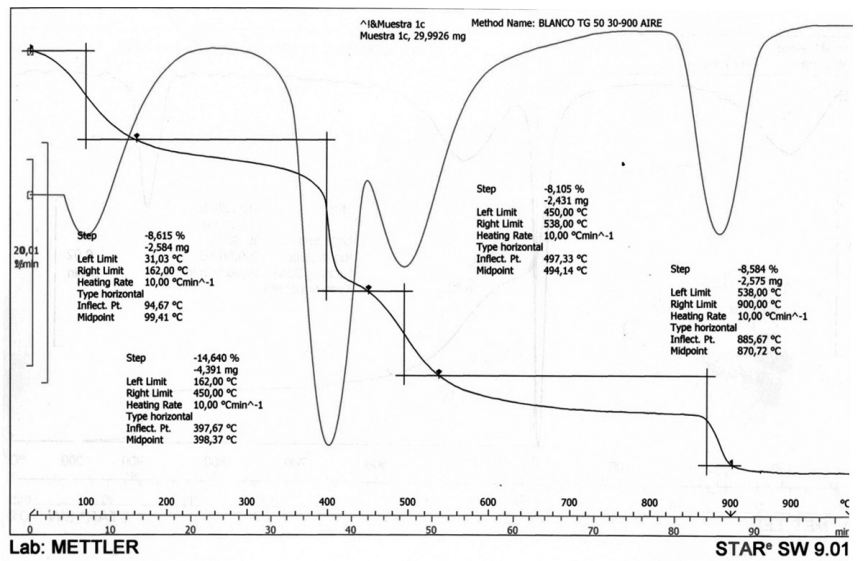

